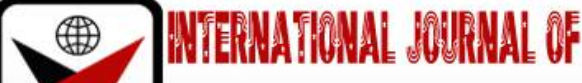

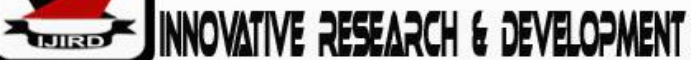

ISSN 2278-0211 (Online)

\section{Enhancing the Effectiveness of Government Policies on Youth Empowerment in Nigeria}

\author{
Dr. D.G. Ishor \\ Senior Lecturer, Department of Social Work, Federal University, Lafia, Nigeria \\ Samuel T. Ioramee \\ Research Student, Department of Business Administration, University of Jos, Nigeria
}

\begin{abstract}
:
The prevalence of youth unemployment and poverty in Nigeria is alarming. Successive governments have initiated several youth empowerment policies targeted at addressing the problems but these programmes have failed to achieve expected outcomes as poverty and unemployment rates are increasing unabated. The failure of these youth empowerment programmes may be associated with the bottleneck in policy formulation processes hence the study proposes a design thinking model (user-centric approach) to be adopted to enhance the effectiveness of youth empowerment policies. Content analysis method was employed. Juxtaposing design thinking with traditional policy design; this study demonstrates the application of design thinking to policymaking and the need for adoption. Drawing from relevant literature on design thinking and public sector innovation, we argue that design thinking holds the promise of assisting policymakers to create social intervention policies and services that improve the users' experience and enhance public value. If implemented well, it will help improve decision-making, contribute to a more comprehensive problem definition; reduced risks of duplications, inconsistencies, or overlaps; minimized unintended consequences and better appreciate the behavioral dynamics of public sector design, and support effective social problem-solving. We therefore recommend that the establishment of Public Service Innovation (PSI) Labs and design centers will help to foster innovation, turnaround policy initiatives in different public institutions and all levels of governments.
\end{abstract}

Keywords: Design thinking, youth unemployment, poverty, public policymaking, youth empowerment

\section{Introduction}

In an era of increasing complexity in governance challenges, governments around the world are seeking new approaches to understanding policy problems, developing solutions, and improving their decision making (Dorst, 2011; Norman, 2013; Kimbell, 2016; Clarke \& Craft, 2016; Blomkamp, 2018). Globally, one-fifth of young people currently are neither gaining experience in the labour market, nor receiving an income from work, nor enhancing their education and skills (International Labour Organisation (ILO), 2020). Even among young people who are engaged in employment, their situation is far from adequate. Of the 429 million young workers worldwide, around 55 million, or 13 per cent, are suffering extreme poverty; Poverty in this study is defined as living on an income below US\$1.90, equivalence of about N750 per day (ILO, 2020).

In Nigeria, youth unemployment and poverty have been identified as some of the complex social problems facing the country with its associated consequences such as the deadly Boko Haram in Northern Nigeria, incessant farmersherders attacks, arm robbery, kidnapping, political thuggery, banditry and trafficking, oil bunkering in the Niger Delta, hence, upsetting the seemingly peaceful and stable socio-political situation in Nigeria (Aiyedogbon \& Ohwofasa, 2012;Ayodeji, Salau \& Adeniyi, 2014; Salami, 2013). Previous studies have adduced the above crimes to the problem of youth unemployment in Nigeria and poverty (Gbandi \& Amissah, 2014; Eme, 2014). ILO (2020) defined unemployment as persons who are currently not working but are willing and able to work for pay, currently available to work and have actively searched for work.

Successive governments in Nigeria have continually made efforts to address the challenges of unemployment and poverty in the country through different policy interventions for youth empowerment such as National Directorate of Employment (NDE), National Poverty Eradication Program (NAPEP), Small and Medium Industries Equity Investment Scheme (SMIES), Youth Entrepreneurship Support Program (YESP), Social Intervention Fund (SIF), Graduate Internship Scheme (GIS), Subsidy Reinvestment and Empowerment Programme (SURE-P), Youth Enterprise with Innovation in Nigeria (YouWIN),N-Power, Youth Empowering People (YEP), Youth Initiative for Sustainable Agriculture in Nigeria (YISAN) and many others were set up to alleviate the challenge of unemployment (Agwu, Onwuegbuzie \& Ezeifeka, 2017; Kalagbor \& Harry, 2018; Waziri \& Abu, 2019).Youth empowerment according to Amadi \& Abdullahi (2012) is a capacitybuilding that implies vocational training and skills development that prepares the youth to be productive in the society. 
Scholars have found that there is a positive relationship between youth empowerment, poverty alleviation, and unemployment reduction in Nigeria (Emeh, 2012; Aminu \& Onimisi, 2014; Ekong \& Ekong, 2016; Waziri \& Abu, 2019).

However, most of theseyouth empowerment programmes are embedded with several challenges culminating in their failures (Waziri \& Abu, 2019); consequently, unemployment and poverty levels are on a steady increase. Data from the World Poverty Clock (2019) has indicated that 92,441,548 million people from a population of about 200,369,312 million representing 46.12 percent of Nigerians living in extreme poverty on less than 1.9dollars a day. The National Bureau of Statistics (2019) reported that 23.1 percent of youths in Nigeria are unemployed and 16.6 percent are underemployed. It is projected that unemployment may reach 33.5 percent by 2020 (NBS, 2019).This ugly trend was corroborated by the Nigerian Minister of Labour and Employment in a 2-day workshop on "Breaking the Resilience of Unemployment Rates in the Country" held in Abuja when he lamented on the status of Nigeria as the "global poverty capital" (World Bank, 2018) and the steady rise of unemployment rates in Nigeria (NBS, 2019). The Minister wondered why the various social interventions targeted at reducing youth unemployment and eradicating poverty have not yielded expected results. He interrogated if there are things the government and other stakeholders were not doing right and what changes are needed in the policies, plans, and strategies (Premium Times Agency Report, May 2, 2019).These statistics and concerns are confirmation of the ineffectiveness in the intervention's efforts by the government for unemployment and poverty eradication in Nigeria.

Extant studies have found that lack of government commitment, lack of funds, corruption, bad leadership, laziness among the youth, inconsistencies in government policies, poor educational development, etc. are responsible for the ineffectiveness and failures of youth empowerment programs in Nigeria (Waziri \& Abu, 2019; Hussaini, 2014; Aminu, \& Onimisi, 2014). Though several recommendations have been suggested to enhance the effectiveness of these youth empowerment programmes, their impact on unemployment and poverty reduction is still something to be desired. Research has shown that most youth empowerment programmes are initiated without consulting the actual beneficiaries (Agwu, 2019; Isa \& Vambe, 2013; Akande, 2016). In effect, there is a need to evaluate if the ineffectiveness and failures of the youth empowerment schemes are associated with bottlenecks in policy formulation processes hence this study proposes a design thinking model (user or beneficiary centered approach) to be adopted to enhance the effectiveness of policy formulation especially youth empowerment policies.

Design thinking has emerged as a promising innovative approach to a public service organization and decisionmaking in addressingopen-ended and complex challenges (Alllo, 2014; Clarke \& Craft, 2018; Lewis, McGann, \& Blomkamp, 2020). Design thinking challenges the traditional public policy formulation and decision-making paradigm where politicians hand down policies meant to benefit citizens without including them in the decision-making process to determine their needs, feelings, motivations, and desires (Kolko, 2018; Isa \& Vambe, 2013). Design thinking constitutes a 'bottom-up' approach where the gap between policymakers and citizens is narrowed through decisions being informed and even sometimes driven by those who are affected by policies. This approach emphasizes end-users needs rather than legacy and policy at the center of the policy formulation, shifting paradigms, and creating a new decisional process. It is an explicit human and user-centered approach because the beneficiaries of the policies are no longer considered merely passive receivers at the end of the regulatory, administrative, and public service delivery chain (Alllo, 2014).

Governments across the world have adopted the design thinking approach and many more are making efforts to the adopt the policy thinking approach to co-create public policy interventions with professionals, the non-public sector, civil society representatives, and citizens. For example, the Australian Tax workplace (AT0) was the primary Australian administrative body to include style thinking as presently understood (Preston 2004 cited in Mintrom \& Luetjens, 2016; Australian Public Service Innovation Action Plan, 2011). In Singapore, the Ministry of Manpower redesigned the Process of Employment Pass Application with the help of the Innovation Design Engineering Organisation (IDE0, 2015; Brown, 2009). United Nations International Children's Emergency Fund (UNICEF) is also using empathy-driven design approaches in Nicaragua to better understand children's situations and enhance policies (Brown, 2008).Other important European examples of public bodies promoting design are SITRA (a public fund aimed at a better Finland tomorrow) in Finland with its Helsinki Design Lab, the Design Council in the UK, and Region 27 in France (Mulgan, 2014). Most of them operate in the administrative ambit with great success. In this respect, Nigeria could draw insights on several best practices from other countries adopting this approach.

Despite the wide-spread interest in design thinking among practitioners, there remains an internal need to demonstrate its usefulness in public policymaking in Nigeria. This study is set to demonstrate how the adoption of design thinking model will increase the quality of policy interventions on youth empowerment in Nigeria. This study is apt and timely because of the glaring ineffectiveness and failure of most youth empowerment policies hence the need for government and other stakeholders to adopt design thinking in policy formulation and implementation. If implemented well, design thinking approaches will help improve decision-making, contributing to a more comprehensive problem definition; reduced risks of duplications, inconsistencies or overlaps; minimized unintended consequences, and more legitimized and effective decisions.

\section{Method}

This study adopted a qualitative approach and content analysis was employed. The study utilized the design thinking model proposed by the D. School (Plattner, 2010) and other related literature on design thinking, youth empowerment, poverty, and unemployment in Nigeria for analysis. 


\section{Literature}

\subsection{Concept of Design Thinking}

Design thinking also known as human-centric design (HCD) is an innovative problem-solving approach that puts the user (the target market or a client) at the core of thought in order to arrive at novel solutions that genuinely reflect the user's needs and desires (Milkowska, 2018). It has become a preferred approach for governments round the globe to handle advanced governance challenges (Clarke \& Craft, 2018). To date, no universally accepted definition has emerged of what constitutes style thinking as most of the definitions are context-based. Design thinking has its roots in several fields like engineering, design, design, arts and humanities, politics, political economy, innovation, science, and management science (Chesson, 2017) with every space exposing a part of design thinking that is vital to our overall understanding of the thought. According to Mintrom \& Leutjens (2016), designed thinking could be a problem-solving approach characterised by curiosity and fellow feeling that seeks to interpret how its targeted populations have interaction with their world. Design thinking is additionally cited as a strategy to address wicked problems (Kumar, 2017). A wicked problem could be a social or cultural downside that is tough to or not possible to unravel ordinarily as a result of its advanced and interconnected nature e.g. poverty, climate change, education, unemployment (Wong, 2019). Rittel's opinion of wicked problems as cited in Buchanan (1992) are a category of social structure issues that are ill-formulated, the data on the market on the issues is confusing and also there are many consumers and decision-makers with conflicting values and the consequence within the whole system are completely confusing.

For design thinkers, this phenomenological orientation implies that policymaking ought to be target-hunting by the values of "empathy" and "curiosity", in conjunction with 'rationality' (Mintrom \& Harry, 2016), and attention on 'crafting new solutions with folks, not only for them' (Carstensen and Bason, 2012). Interactive Design Foundation delineate design thinking as a non-linear, repetitive method that seeks to know users, challenges assumptions, redefine issues in an attempt to craft various methods and solutions which may not be instantly apparent with our initial understanding. Design thinking is made on numerous faculties of thought and is grounded on fellow feelings, listening, and iteration. It is helpful in effort to resolving advanced challenges (wicked problems) that are ill-defined or unknown by understanding the human desires concerned, by reframing the matter in human-centric ways in which, by making several concepts in group action sessions, and adopting an active approach in prototyping and testing.

Design thinking has the potential to enhance downside definition and mechanism approach in policymaking processes. Thus, design thinking is to equip governments with innovative approaches to face up to date challenges like inter-connected and subtle economic and social patterns. Drawing from non-public sector experiences, design thinking seeks to stimulate creativeness inside the decision-making method and accelerate the synthesis of progressively effective and economic policy solutions. Framing the matter properly from the beginning could be a pre-condition for the emotive evolution of the phases of policy formulation, development, adoption, and implementation. It's necessary to indicate that the planning thinking method cannot replace the traditional methods fully however rather complement and support the normal call process particularly at the abstract part. The social control transient is to manage policy development and policy consultation so everybody concerned understands why they are being consulted, how consultation is being sequenced, and incorporating the requirements of the target users within the policy.

\section{Theoretical Framework}

\subsection{Design Thinking in Policymaking}

There are many schools of thought of the design thinking but the core pillars of the process are consistent and include deep empathy, listening and relating to the user, testing through rapid and cheap prototyping, and constant iteration (Mintrom \& Leutjens, 2016). According to Kimbell (2011), the design thinking research line is developed in three models through time. This first one, originated by Simon (1969), continued to be studied as a cognitive style, being proposed for resolving ill-structured problems. Simon (1969) in his book, "The Sciences of the Artificial" argued that 'the intellectual activity that produces material work of art is no different fundamentally from the one that advocate therapy for a sick patient... or a social welfare policy for a state' (p. 55-56). The ability to iterate, test, and progressively develop designs is fundamental to Simon's model. Simon consequently expanded the scope of his design focus to social planning. For him, such planning ideally was intended to help decision makers 'appraise option better' and 'appreciate the world better' (1996:130).The second line aims to solve wicked problems. This design thinking is mainly seen as a design theory, being championed by authors such as Buchanan (1992) and Goldschmidt (1997). Finally, the third one is the overview of Design thinking as an organizational resource that aims to bring user-centered innovation and creativity (Plattner, 2010). Many authors supported this approach, such as (Brown, 2008; Leavy, 2010; Martin, 2010).

Design thinking as an organizational resource became a new trend due to recent popularization efforts, such as those of IDEO (Brown 2008) and the many success recorded by high profiled global organizations such as Google, Apple and Airbus have implemented it to notable effect (Teo, \& Interactive Design Foundation, 2002).Since then, Design Thinking has been hyped for applications on product development, however additionally on management and strategic innovation (Leavy 2010), education (Rauth et al. 2010), social design (Sklar and Madsen 2010), Poverty reduction (Hodgett, et al, 2013), unemployment (Murphy, 2004; Brown, 2008) among others. In this study, the five-phased model proposed by (Plattner, \& Bootcamp, 2010; Alllo, 2014; Rosa, \& Rozenfeld, 2016) was adapted. The models offer a decent depiction of the worth of logical structure for examining public policies. The five phases of design thinking are presented in figure 1. 


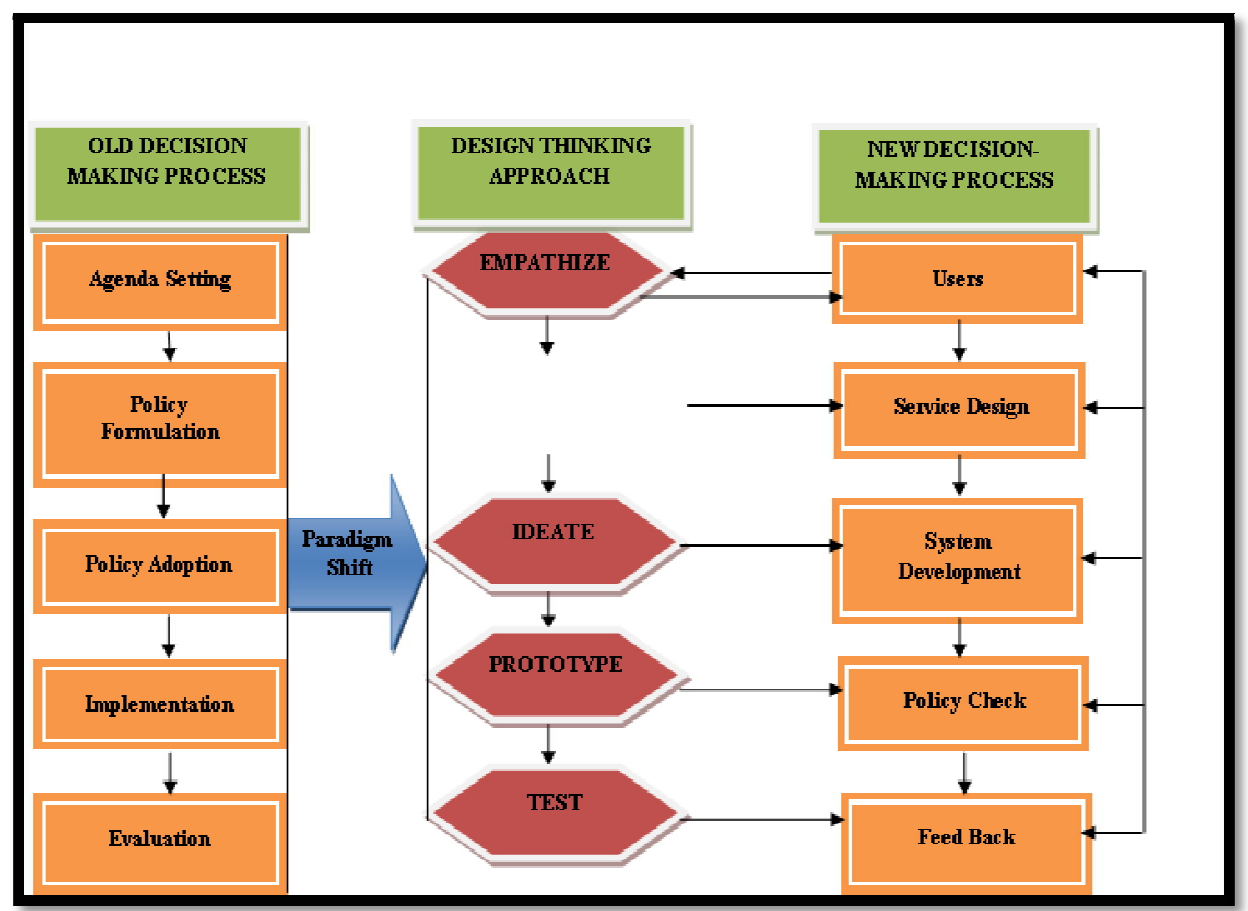

Figure 1: Designed Thinking Model for Policy Formulation: A Five Stage Process Source: Adapted from Plattner \& Bootcamp (2010), Allo (2014), Howlet \& Ramesh, 2013

Traditionally, policymaking has been characterized as a rational method involving a linear path from agendasetting to the analysis of choices and development of policy solutions and implementation (Mintrom \& Leutjens, 2016; National cooperative Center for Healthy Public Policy, 2013; Howlet \& Ramesh, 2013; 2003). Current public formulation usually pivots round the logics of the supplier instead of those of the user, a gaggle which may embody citizens, businesses, or different end-recipients of policies and services. As seen in figure 1, the previous policymaking method is top-down with the targeted users not involved at any stage within the model. Often, people that are perhaps to use government services or policies are not contacted once the policy has been designed, the method set out and therefore the system originated (Scott, 2018).

This approach is a reflection of the elite theory by Mills (1956) that was widely criticized. From the views of elite theory, public policy is thought to be reflecting the values and preferences of the governing elite (Anyebe, 2018). The essential argument of the elite theory is that public policy isn't determined by the strain and actions of the individuals or the plenty however rather by a ruling elite whose preferences are carried into impact by political officers and agencies. In other words, the elites believed that they alone will bear out the policies to push the welfare of the citizens and implement them. Therefore, policies flow downward from the elite to the citizens. The policies created by the elites mirror elite values and prefer the established order to radical changes. The consequence of this assumption is that the overall people or the plenty are apathetic, ill-informed, and don't confirm or influence policy through their demands or actions.

Increasingly, this view is being contested thanks to the inherent complexities facing the general public sector. In complicated systems like Nigeria, well-intended interventions usually have unplanned consequences (Shergold, 2015). It's to this effect that design thinking emerges as associate degree approach to addressing complicated social issues. Design thinking assuming results from some essential elements that follow a non-linear method of empathizing with the target users to grasp how they think, feel and the peculiarity of their challenges; then outline the wants of the target users, their issues and transfer insights; ideating by challenging assumptions and making ideas for solutions; prototyping to start out making solutions and eventually testing the known solutions and gathering feedback from the users to judge the workability and match of the answer to the matter. The unvaried method is heavily captivated with receiving and incorporating feedback to enhance the method. A seen in figure 1, feedback is required at each stage until a positive feedback from users is achieved. It suffices to notice that the 5 stages or phases will usually occur parallel and repeat iteratively. The application of the design thinking stages in policymaking is mentioned and discussed in this section.

\subsection{Empathy}

Empathy is the foundation of the humane style method. It is the capability to use emotional and social intelligence to achieve insight into target groups' thoughts, feelings, motivations, and wishes (Stevens, 2019). Developing empathy is about practically bringing public administrators outside their office; confronting them with real-life situations, and helping them directly grasp users' challenges and expectations. Staring at social issues from the window of a public administration edifice is not a strategy for achieving success. Policies should be designed with individuals and not just for them. So, understanding on how people think and feel, how they behave, what they are not getting is at the heart of creating policies and laws that truly serve peoples' needs. Collaboration is critical once featured with a complex challenge because innovation is unlikely to occur in isolation.

Design thinking starts with 'professional empathy' among clusters of stakeholders by perceptive users and their behavior in their context, through interview of users to gain expertise and knowledge of the problem and what they 
experience (Bason, 2010). Empathizing bridges the gulf between the regulators/service suppliers and users. It additionally helps disentangle variations between the 'needs' and 'wants' of users. Co-creation is indispensable if governments are to handle new social objectives. Co-creation implies transfer analysts and decision-makers to confront real-life things as older by the end-users. Junginger (2015) argued that it's necessary to co-design, co-develop, co-create and co-produce to grasp issues not solely from the lenses of the general public organization or the lawmakers however additionally from the lenses of the everyday subject.

Bason explains co-creation in 2 sectors; "the attention witnessed a shift from 'curing diseases' to 'enabling quality of life'.. In a job policy, the trouble has shifted from 'finding individuals a job' to 'enhancing employability" (Bason, 2010:158). Such interaction will take totally different forms, together with increased public consultation and neutral engagement practices or on-line opinion survey from end-users of projected policies. Often, policymaking in Nigeria and many African Nations incorporates consultation with stakeholders late in the process usually after problem definition has occurred, options have been analysed, and broadly acceptable ways forward have been explored; Consulting at later stage increase the danger of the consultation being interpreted as a mere formality, intended to limit the ability of stakeholders to seriously inform mechanism design. Nigeria and African Nations will draw lessons from this phase and revisit policy formulation on unemployment and poverty reduction.

\subsection{Defining the Problem}

Academics and public commentators have highlighted the use of design thinking as a way to inform problem definition (Dorst and Cross 20011; Liedtka, Andrew, \& Kevin, 2013). Defining the problem occurs when you unpack and synthesis your empathy findings into compelling insights. This is to enable the policy designer to gain focus on an actionable point of view and develop a guiding statement that focuses on specific users, insights, and needs identified during the empathy stage. Scaling is an integral part of mapping the problem at hand, which includes looking at the underlying causes, determining baseline scenarios, and projecting possible trends in the problem evolution (Alllo, 2014). Applying scalar thinking increases objectivity, skepticism, and compound vision. Scaling has practical implications for the design of realistic and effective policy decisions. Decision-makers must be aware not only of the size of the problem but also of the scale of the possible solutions that can be deployed to address. This affect the evaluation of the probable impacts that selected options may generate.

The Elements of design thinking have long been applied in social sciences research and public administration. What is new however, the element is new is how those elements are now combined to produce powerful insight into citizens' actions and their interaction with governments. For example, rather than having policymakers define and understand the problem from an agency or government perspective, design thinking offers a different aspect of the problem to engage. Sometimes, the problem that is defined may not be the problem that needs to be solved. Tackling unemployment and poverty are not an easy task to achieve therefore it is easier for government to adopt familiar solutions always as the case in Nigeria where successive governments keep introducing all kinds of social interventions under different or modified nomenclatures without understanding the cause of the problem and the need of the target beneficiaries (Kolko, 2018; Isa \& Vambe, 2013). This can produce abstract and sensible traps. It is potentially much more productive though much harder to look past the existing solutions to search for more radical and effective ones.

In the context of this study, adopting design thinking model to reduce youth unemployment and poverty, the following questions proposed by Mintron \& Leutjens (2016) may be useful at the stage of empathy and problem definition;

- Where are the highest areas of youth unemployment at present?

- What factors appear to engender youth unemployment?

- Where is youth unemployment likely to emerge as a problem in the coming years?

- How are job-seeking strategies of the long-term unemployed different from those of the short-term unemployed?

- Under what circumstances does youth unemployment lead to other problems, such as teen pregnancy, substance dependency, or criminal activity?

- What do unemployed youth want from service providers?

- What are some success stories of interventions that have assisted youth to gain stable, long-term employment? These set of questions specific to youth unemployment could be readily adapted to prompt design thinking across a broad range of areas where some form of government support is considered necessary to improve social outcomes.

\subsection{Ideation}

Once there is a well-defined or reframed problem, a wide range of ideas are generated through structured brainstorming around possible solutions to address identified challenges. Design thinking is multidisciplinary and ideating thrives on the presence of a variety of disciplines working on a specific problem. Each discipline is given equal place during the brainstorming sessions which removes the problem of creating solutions in isolation.

\subsection{Prototyping}

One of the most visible outputs of design thinking is policy prototypes. A prototype is an early sample, model, or release of a product built to test a concept or process or to act as a thing to be replicated or learned from. This involves getting ideas and explorations out of the mind of the designer and the mind of others into the physical world. Prototypes are conceived to test new systems to enhance precision by system analysts and users. Prototyping serves to produce specifications for a true, operating system instead of a theoretical one. Prototyping improves the standard of the specifications and necessities provided to end users. A prototype of service can take many forms, such as a graphical user scenario (a storyboard), a film, a play or enactment, or a mock-up of a web interface. Prototyping encourages a culture of 
openness and provides a way to collaborate with others to reflect on feedback received about a potential solution to develop a more viable policy (Benson \& Dresdow, 2015). The iteration might be executed several times until the user feedback is positive. Implementing prototyping to public service innovation goes beyond the traditional notion of 'piloting' (Bason, 2010). Design thinking prototypes shaped the lines not only of internal disciplines and hierarchies but also the decisional system and the users. Prototyping of new public service delivery will set different challenges than designing and testing fully-fledged public policies (Nesta, 2011).

\subsection{Testing}

In this phase, designers or policymakers rigorously test the developed systems using the best solutions identified during the brainstorming and prototyping stage. This is the final stage of the five staged model but an iterative process. This is achieved bytesting the idea of potential users. The feedback can then be used to iterate the prototype or to improve the concept. In line with the iterative nature of design thinking, testing prototypes along the process allows a team to observe the users' responses to a potential solution before it is finalized. The iteration might be executed several times until the user feedback is positive. Often, lack of time is cited as a reason to avoid prototyping and testing but it is imperative that prototyping and testing be allotted the necessary time to make it possible to reflect and incorporate the feedback in the final solution to the identified problem.

\section{Design Thinking Strategies and Their Potential Uses in Policymaking}

The application of design thinking requires a sound knowledge of the targeted people through public engagement to gather views and prototyping interventions would need the reinvention of key aspects of policymaking. Here we offer a non-exhaustive illustrative list of specific design strategies and their potential use in policymaking. These are; (1) environmental scanning, (2) participant observation, (3) open-to-learning conversations, (4) mapping, and (5) sensemaking.

\subsection{Environmental Scanning}

This strategy seeks to spot trends which will influence future outcomes. It needs taking stock of a specific scenario and scanning for brand spanking new inputs, materials, influences, and technologies applied in different fields which will be relevant (Mintrom \& Leutjens, 2016). Environmental scanning is meant to fill data gaps and develop holistic understandings of systems. It should embrace user views. This opens the chance for the strategy to lift the sympathy of policy developers towards end-users of state services. Environmental scanning casts a large web, exploring things in several ways, and fascinating data from areas not essentially thought-about in ancient policymaking processes. Questioning the information and proof helps policy developers get back long assumptions, and review current policy settings. The strategy is used once considering a replacement policy space or up a policy that is presently in situation. Thus, adopting the anthropology approach and methodology of information assortment are useful as a result of this system can modify the designer to be told regarding the participant's activities and desires, instead of build assumptions. Sometimes, the policy designers could establish the wants, supported observations and interviews.

\subsection{Participant Observation}

Observation refers to the power to note vital and ostensibly insignificant details to assemble information (Mintrom \& Leutjens, 2016). In developing a framework for understanding information science in problem-solving tasks, Newell and Simon (1972) cited in Mintrom \& Leutjens (2016) powerfully stressed the importance of task effects on call behaviour. They contended that a theory of problem-solving cannot predict behaviour unless it encompasses each collaborative analysis of the task and also the limits of rational adaptation to task needs. Though, environmental scanning facilitates the broad exploration of a difficulty, observation needs participating with individuals encountering specific issues. Design thinking applies observation to know individuals and their behaviour within the context of their lives. During this context as in several others, sympathy is essential to effective observation (Wagenaar, 2014).

\subsection{Open-to-Learning Conversations}

The key to facilitating conversations is to try to outline and redefine the matter statement, supported by the feedback and insights drawn from the cluster. This permits for challenging the assumptions and create a mental act concept. Single-loop learning suggests that once one thing goes wrong, individuals ask for alternate methods which will address and work at intervals. In double-loop learning, the alternate response is to question the prevailing alternative set. Double-loop learning, or thinking, is that the route to innovation to realize new ideas. This strategy is vital to own a various cluster of individuals concerned within the method. Open-to-learning conversations encourage thinking (Mintrom, \& Leutjens, 2016). Such conversations facilitate analysing existing choices and questioning the elemental basis of existing structures. Though this method is non-linear, initial analysis and exploration are needed to produce a structure that allows the helper to dig deeper and capture findings from the cluster. The key to facilitating conversations is to try to outline and redefine the matter statement, supported by the feedback and insights drawn from the cluster. This permits for the difficult of assumptions and create by mental act concepts.

\subsection{Mapping}

Mapping is accustomed perceive however totally different concepts relate to at least one another. it's long been utilized in policymaking to explore the links between mechanism style and implementation (Elmore 1979). Mapping is accustomed consistently visualise human experiences and rely on steps or 'touch points' of a method. Typically, in ancient policymaking, downside statements are thought-about in isolation from relevant contextualization. Journey mapping 
communicates the user expertise from commencing to finish and offers broader, subtle, and holistic data of user experiences. It will reveal issues and facilitate recommend alternate pathways forward. This may be a really powerful remedy to self-complacency and a decent thanks to challenge standard thinking.

\subsection{Sense Making}

Kolko (2015) outlined sense-making as a progress social retrospective method grounded in identity construction, driven by credibility instead of accuracy. It's a collaborative action-oriented method that individuals mechanically undergo to integrate experiences into their understanding of the globe around them in effort to produce information. Dialogue is essential to sense making. Once information and insights are externalized, say with the use of paper notes on the wall, designers will begin a lot of intellectual task of distinguishing express and implicit relationships, physically drawing out these content affinities through the method of organisation. This method requires semantic shifting viewpoint in order to see things differently.

\subsection{Review of Countries Adopting Design Thinking}

Auckland City Mission launched the Family 100 project in an attempt to understand the complexity of the repeating cycle of poverty. Over 12 months, the team worked with 100 families who were long-term users of the Mission's food bank. Team members sought to gain a deeper understanding of the life experiences of families in poverty. One key focus of the Project was to map participants' interactions with a variety of agencies to reveal how individuals navigate a posh service landscape to ensure their needs are met (Hodgetts et al. 2013a). The project unleashed a variety of insights into justice, debt, health, education, employment, housing, food and services, and the way these areas were related. The Government of Canada has introduced a series of innovation and design labs, in both central agencies (the Central Innovation Hub in Privy Council Office) and line departments (in Innovation, Science and Economic Development Canada, Employment and Social Development Canada, and Natural Resources Canada) Tonurist, Kattel, \& Lember, (2017). Similarly, the Australian Public Service Innovation Action Plan (2011) led to the APS Design Lab and the Australian Centre for Public Sector Design.The United Kingdom's activity Insights Team, originally developed within the Prime Minister's workplace and currently managed as a social purpose company at arm's length from government, was not strictly for creating "innovation" or "design" work, however it will draw on a strategy usually applied in design thinking activity insights and emphasizes user engagement, prototyping, and experimentation "making public services more cost-effective and easier for citizens to use, up outcomes by introducing a further realistic model of human behaviour to policy; and wherever possible(The activity Insights Team, 2017). At the municipal level, Kent council developed the Social Innovation work for Kent (SILK). Aiming to do policy otherwise," as they describe their work, The SILK Methodology provides inventive and innovative ways to have interaction with citizens and approach comes, and allows collective possession and responsibility for project style, delivery and outcomes" (Social Innovation work for Kent, 2015).

From the review, it is obvious that aspects of design thinking are already occurring in the general public sector context quite with success and progressively several governments are recognising the worth of public input in policy development. However, some countries are however yet to embrace design thinking as a part of their governmental systems particularly developing nations like Nigeria. This could be as a result of design thinking in its purest kind doesn't work with thought public policymaking processes. Also, some factors might have an effect on the propensity of rising societies like Nigeria to understand the character and edges of design thinking together with political and social resistance, degree of maturity and cognizance of people and civil society as a full, deference to authority, and also the power distance between the state and citizens (Alllo, 2014). However, by promoting a bigger understanding of what users expect from government services, design thinking will support public managers who need to boost public worth.

\section{Conclusions and Recommendations}

\subsection{Conclusion}

Design thinking is both a philosophy and procedure concerned with resolving multifaceted challenges in a humancentric manner. Design thinking holds the promise of assisting policymakers to create interventions and services that improve the users' experience and enhance public value. It is established that early engagement with target users is most likely to enhance policy design, program development, implementation, and social outcomes (Mintrom \& Leutjens, 2016). Design thinking is not a panacea, nor does it seek to displace or override existing forms of policymaking. There are certain instances where traditional approaches to the design and implementation of public policy are necessary and preferable (Rhodes 2015). However, design thinking offers an alternative view of how the government might interact with and include citizens in its decision-making processes. Empowerment intervention policies that accommodate the input of the target beneficiaries at the point of policy formulation holds the promise to deliver powerful results in reducing unemployment and poverty in Nigeria.

\subsection{Recommendations}

The success of public service innovative approach is contingent on the diversity of skills and abilities, therefore, to fully institutionalize design thinking in policymaking processes, careful consideration should be paid to the skills that would be required of policy analysts and how cross-agency and cross-jurisdictional relations could be more effectively managed to support policy development. This could be addressed by building the capacity of public sector administrators to use the design method and to procure design effectively. Further action points for decision-making in Europe where design thinking is popular include establishing design labs within the organization or partnering existing design labs to 
support policy design and implementation. This model can be replicated in Nigeria by building public administrators' capacities as well as partnering with an existing design or boundary-spanning organisations, committed to ensuring best practice in policymaking to enhance decision making processes especially policies on youth empowerment and poverty alleviation. Establishment of Public Service Innovation (PSI) Labs and design centers will help to foster innovation, spin-off initiatives in different public institutions and levels of governments, and train civil servants in the application of design thinking approaches. Design thinking is likely to become more institutionalized if it results from a new social contract arrangement in which there is trust.

This study is significant because by promoting greater understanding and insight on design thinking can support government policy design processes and enhance the effectiveness of government policies on how citizens experience government services and reduce the risks of partial approaches, duplicated efforts, policy inconsistencies or overlaps and unintended consequences, enhanced synergies and better-addressed trade-offs, integrated and better-targeted solutions and stronger reality checks at earlier stages; and higher chances to deliver more complete and resilient solutions. Special considerations for how and when to measure impacts of design thinking is crucial for long term sustainability. This study provides useful insights on improving policy-making processes by demonstrating the need to adopt the user-centered approach, the design thinking capacities of policymakers

\section{References}

i. Agwu, E. (2019). Government assisted programs and unemployment reduction in developing economies: A study of Nigeria and Ghana, International Journal of Management, Economics and Social Sciences8(4), 280- 298, http://dx.doi.org/10.32327/IJMESS/8.4.2019.1

ii. Agwu, M. E., Onwuegbuzie, H. N. \& Ezeifeka, P. (2017). Impact of entrepreneurship education on new ventures creation - A case study. Advances in Social Sciences Research Journal, 4(25), 98-114.

iii. Aiyedogbon, J.O. \& Ohwofasa, B.O. (2012). Poverty and youth unemployment in Nigeria, 1987-2011. International Journal of Business and Social Science, 3(20).

iv. Akande, T. (2016). The State of Youth Unemployment in Nigeria. A publication of Nigerian Institute of Social and Economic Research.

v. Alllo, L. (2014). Design Thinking for Public Service Excellence. UNDPGlobal Centre for Public Service.

vi. Amadi, O. B. \& Abdullah, H. (2012). "Perception of Capacity Building among Youths Involvedin Vocational Skills Development". Journal of Social and Development Sciences. 3(6), 214-221.

vii. Aminu, I., \& Onimisi, T. (2014). Policy Implementation and the Challenges of Poverty Alleviation in Nigeria. Academic Journal of Interdisciplinary Studies, 3(4), 295.

viii. Anyebe, A. A. (2018). An Overview of Approaches to the Study of Public Policy. International Journal of Political Science (IJPS), 4(1), 08-17.

ix. Bason, C. (2010). Leading public sector innovation: Co-creating for a better society. Bristol, UK: Policy Press.

x. Bason, C. (2013). Discovering co-production by design. In E. Manzini \& E. Staszowski (Eds.), Public and collaborative: Exploring the intersections of design, social innovation, and public policy, 8-16, New York: DESIS Network.

xi. Bason, C. (2017). Leading public design: Human-centered governance. Bristol, UK: Policy Press.

xii. Bason, C. (Ed.). (2014). Design for Policy. New York, NY: Routledge.

xiii. Behavioural Insights Team. (2017). Who We Are. Available at: https://www.behaviouralinsights.co.uk Retrieved on 11 th may, 2020.

xiv. Blanka, T., Mitja, R., \& Tine, N. (2018) User-driven innovation: scale development and validation. Economic Research-Ekonomska Istraživanja, 31:1, 1472-1487, DOI: 10.1080/1331677X.2018.1484784

xv. Blomkamp, E. (2018). The promise of co-design for public policy. Australian Journal of Public Administration.77(4), 729-743.

xvi. Brown, T. (2008). 'Design Thinking'. Harvard Business Review 86(6), 84.

xvii. Brown, T. (2009). Change by Design: How Design Thinking Transforms Organisation and Inspires Innovation. New York, NY: Harper Collins.

xviii. Buchanan, R. (1992). "Wicked Problems in Design Thinking." Design Issues 8(2), 5-21.

xix. Buchenau, M. \& Suri, J.F. (2000). Experience prototyping, in Proceedings of the 3rd conference on Designing interactive systems: processes, practices, methods, and techniques.

xx. Chesson, D. (2017). Design Thinker Profile: Creating and Validating a Scale for Measuring Design Thinking Capabilities. Dissertations \& Theses. Available on:http://aura.antioch.edu/etds/388 Retrieved on 5th May, 2020.

xxi. Clarke A., \& Craft J. (2019). The twin faces of public sector design. Governance. 5-21. https://doi.org/10.1111/gove.12342

xxii. Clarke, A., \& Craft, J. (2017). The vestiges and vanguards of policy design in a digital context. Canadian Public Administration, 60(4), 476-497.

xxiii. Craft, J., \& Howlett, M. (2012). Policy formulation, governance shifts and policy influence: Location and content in policy advisory systems. Journal of Public Policy, 32(02), 79-98.

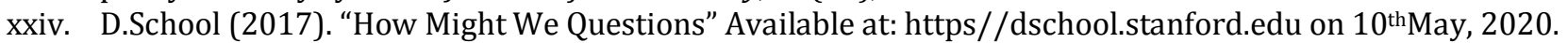

xxv. Dorst, K., (2011). The core of Design Thinking and its application, Design Studies, 32(6), 521-532.

xxvi. Ekong, U.M., \& Ekong, C.U. (2016). Skills Acquisition and Unemployment Reduction in Nigeria. A case study of the National Directorate of Employment (NDE), Akwa-Ibom State. International Journal of Economics and Management Sciences. 
xxvii. Emeh, I.E.J. (2012). Tackling Youth Unemployment in Nigeria: The Lagos State Development and Empowerment Programmes Initiatives. Afro Asian Journal of Social Sciences, 3(3).

xxviii. Frey, C. (2020). How can Design Thinking be applied to government policy-making? Available at Innovation Management.se. Retrieved on $10^{\text {th }}$ May, 2020

xxix. Harry, D.M. (2017), Dearth of Scientific Research Data in Policy-Making as Development. Challenge in Nigeria: A Critical Appraisal. Journal of Sustainable Development in Africa, 19 (4), 1-12.

xxx. Hodgetts, D., Kerry, C., Yardena, T., \& Shiloh G. (2013b). 'Researching Poverty to Make a Difference: The Need for Reciprocity and Advocacy in Community Research'. Australian Community Psychologist 25(1):35- 48.

xxxi. Howlett, M., and Ramesh, M. (2013). Policy Models and their usefulness in Public Health: Stages Model. National Collaborative Center for Health Public Policy.

xxxii. Howlett, M., Wellstead, A., \& Craft, J. (2017). Policy work in Canada: Professional practices and analytical capacities. Toronto, Canada: University of Toronto Press.

xxxiii. Hussaini, M. (2014). Poverty alleviation programs in Nigeria: Issues and challenges. International Journal of Development Research, 4(3), 717-720.

xxxiv. IDEO (2015). The Field guide to Human-Centered Design. (1 ${ }^{\text {st }}$ ed.) IDEO.org, USA.

xxxv. International Labour Organisation (2020). Global Employment Trens for Youth, 2020: Technology and the future of Jobs. International Labour Office, Geneva.

xxxvi. Isa, A.M. \& Vambe, J. (2013), Youth Empowerment and National Development in Nigeria. International Journal of Business and Management Invention, 2(10), 82 - 88.

xxxvii. Junginger, S. (2015). A design perspective on Nudging. Hertic School of Governance

xxxviii. Kalagbor, S.B. \& Harry,D.M. (2018). Youth Empowerment and National Security in Nigeria: Issues and Prospects. Global Journal of Political Science and Administration, 6(3), 1-14.

xxxix. Kimbell, L. (2016). Applying design approaches to policymaking: Discovering the policy lab. Brighton: University of Brighton.

xl. Kimbell, L., (2011). Rethinking Design Thinking: Part I, Design and Culture, 13(3), 285-306.

xli. Kolko, J. (2015) Design Thinking Comes of Age. Available at: https://hbr.org/2015/09/design-thinking-comesof-age. Retrieved on the 14th May, 2020.

xlii. Kumar, V.D. (2017). Design Thinking and Wicked Problems. Available at https//hackernoon.com. Retrieved on the $5^{\text {th }}$ May, 2020.

xliii. Lewis, J.M., McGann, M. \& Blomkamp, E. (2019). When design meets power: Design thinking, Public Sector Innovation, and the Politics of Policymaking, Policy \& Politics, 48(1), 111-130,DOI: 10.1332/030557319X15579230420081.

xliv. Liedtka, J., Andrew K., \& Kevin, B. (2013). Solving Problems with Design Thinking: Ten Stories of What Works. New York, NY: Columbia University Press.

xlv. Liedtka, J., Ogilvie, T., (2011). Designing for growth: a design thinking tool kit for managers. USA, Columbia University Press.

xlvi. Leavy, B. (2010). Design thinking - a new mental model of value innovation. Strategy \& Leadership, 38(3), 5-14.

xlvii. McGann, M. Blomkamp, E., \& Lewis, J.M. (2018). The rise of public sector innovation labs: Experiments in design thinking for policy. Policy Science. https://doi.org/10.1007/s11077-018-9315-7

xlviii. Meinel, C., Leifer, L., \& Plattner, H. (2011). Design Thinking: Understand, Improve, Apply. Berlin, Springer Publishing Company.

xlix. Milkowska, M. (2018). Design thinking for better Government Services. Policy Management. Available at: https//www.innovations.havard.edu.

l. Mintrom, M., \& Luetjens, J. (2016). Design thinking in policymaking processes: Opportunities and challenges. Australian Journal of Public Administration, 75(3), 391-402.

li. Mulgan, G. (2014). Design thinking in public and social Innovation: What works and what could work.

lii. Murphy, K. (2004), "The role of trust in nurturing compliance: A study of accused tax avoiders. Law and Human Behavior, 28(2), 187-209.

liii. National Bureau of Statistics (2019). Quarterly Report on Unemployment and Poverty in Nigeria. Retrieved from https://www.nigerianstat.gov.ng.

liv. National Collaborative Center for Healthy Public Policy (2013). Policy Models and their usefulness in Public Health. The Stages Model.

lv. Nesta (2011), Prototyping Public Services: An Introduction to Using Prototyping in the Development of Public Services, London.

lvi. NHS Institute for Innovation and Improvement. (2013). Experience-based design: Using patient and staff experience to design better healthcare services. Available at https://www.institute.nhs.uk, Retrieved on $13^{\text {th }}$ May, 20120

lvii. Norman, D. (2013). Rethinking Design Thinking. Core 77.

lviii. Oluta, A., Salami, R., \& Akeremale, I. (2015). Poverty and Rate of unemployment in Nigeria. International Journal of Management and Business, 2(1).

lix. Plattner, H., \& Bootcamp B. (2010). Design School Stanford, Stanford.

lx. Plattner, H. (2010). Bootcamp Bootleg, Design School Stanford, Stanford.

lxi. Plattner, H., Meinel, C., \& Leifer, L (2011). Design Thinking. Berlin: Springer. 
lxii. Portable (n.d.). Hacking the Bureaucracy: Exploring the key drivers of innovation within Government. Available at: $\quad$ Portable.com.au. Retrieved on the $12^{\text {th }}$ May, 20120.

lxiii. Premium Times (2019, 2, May). Agency Report on a 2-days workshop on "Breaking the Resilience of High Unemployment Rate in the Country" Nigeria. Available at: premiumtimesng.com/author/agency report.

lxiv. Relly, J.E. \& Sabharwal, M. (2009). Perception of transparency of government policymaking: A cross-national study. Government Information Quarterly, 26, 148-157.

lxv. Rittel, H.W.J. (1988), The Reasoning of Designers, Institut fur Grundlagen der Planung, Stuttgart.

lxvi. Rosa, M., \& Rozenfeld, H. (2016). Looking for Fundamental Elements of Design Thinking. International Design Conference - Design 2016

lxvii. Rowe, P., (1987)."Design Thinking", MIT Press Massachusetts

lxviii. Salami, C. G. E. (2013). Youth unemployment in Nigeria: A time for creative intervention. International Journal of Business and Marketing Management, 1(2): 18-26.

lxix. Simon, H. A., (1969). The sciences of the Artificial, (3rded.), The MIT Press, Massachusetts

lxx. Scott, D. (2018). Embracing Design Thinking in Government.

lxxi. Shergold, P. (2015). Learning from Failure: Why Large Government Policy Initiatives have gone so badly wrong in the Past and How the Chances of Success in the Future Can be improved. Canberra: Australian Public Service Commission.

lxxii. Simon, H. A., (1969). The sciences of the Artificial", (3 $3^{\text {rd }}$ ed.), The MIT Press, Massachusetts.

lxxiii. Stevens, E. (2019). What is Design Thinking? A comprehensive beginners' Guide. Available at:http//careerfoundry.com. Retrieved on the $12^{\text {th }}$ of May, 2017

lxxiv. Thoring, K., \& Müller, R.M. (2011). Understanding Design Thinking: A Process Model Based on Method Engineering. International Conference on Engineering and Product Design Education, University, $\quad$ London, UK.

lxxv. Tonurist, P., Kattel, R., \& Lember, V. (2017). Innovation Labs in the public sector: What they are and what they do. Public Management Review, (February), 1-25.

lxxvi. Waziri, M. Abu, I. (2019). Youth Empowerment Program in Nigeria: A Strategy for Poverty Alleviation and National Development. Journal of Public Value and Administration Insights (JPVAI) 2(3); 12-14.

Ixxvii. Wong, E. (2019). What is a wicked problem and how can you solve it. Interactive Design Foundation

lxxviii. World Bank (2018). Online poverty data base. Available at: http://povertydata.worldbank.org. Retrieved on the $10^{\text {th }}$ May, 2020.

lxxix. World Poverty Clock (2020). Total number of People Living in Extreme poverty in Nigeria. Available at: https://worldpovert.ioRetrieved on the 14th May, 2020. 